\title{
HIPERTENSI, DIABETES MELITUS, DAN OBESITAS SEBAGAI FAKTOR KOMORBIDITAS UTAMA TERHADAP MORTALITAS PASIEN COVID-19: SEBUAH STUDI LITERATUR
}

\author{
Luh Ade Dita Rahayu, ${ }^{1}$ Jannatul Cahya Admiyanti, ${ }^{1}$ Yumna Iftinan Khalda, ${ }^{1}$ Fatikha \\ Rudia Ahda, ${ }^{1}$ Nur Feby Febiana Agistany, ${ }^{1}$ Sastraningsih Setiawati, ${ }^{1}$ Nabila Indah \\ Shofiyanti, ${ }^{1}$ Cut Warnaini ${ }^{2}$ \\ ${ }^{1}$ Program Studi Pendidikan Dokter, Fakultas Kedokteran, Universitas Mataram, Mataram \\ ${ }^{2}$ Departemen IImu Kesehatan Masyarakat, Fakultas Kedokteran Universitas Mataram, \\ Mataram
}

\begin{abstract}
ABSTRAK
Korespondensi:

Cut Warnaini

Email author:

cut.warnaini@unram.ac.id

Riwayat Artikel

Diterima: 11 April 2021

Selesai revisi: 10 Juni 2021

DOI :

10.53366/jimki.v9i1.342

Pendahuluan: Pasien COVID-19 dengan penyakit penyerta atau komorbid memiliki tingkat kematian yang lebih tinggi dibandingkan dengan pasien tanpa penyakit bawaan. Komorbid yang paling umum dijumpai pada pasien COVID-19 adalah diabetes melitus, hipertensi, dan obesitas. Prevalensi pasien COVID-19 dengan diabetes melitus mencapai $41,7 \%$, hipertensi mencapai $56,6 \%$, dan obesitas mencapai $41,7 \%$.

Metode: Metode yang digunakan dalam penulisan ini adalah studi literatur yang relevan dari berbagai referensi dan terfokus pada hubungan komorbid dengan risiko kematian pada pasien COVID-19. Adapun mesin pencari yang digunakan dalam pencarian literatur antara lain NCBI dan Google Scholar. Secara keseluruhan digunakan sebanyak 21 sumber yang didapat dari berbagai basis meliputi PubMed, ScienceDirect, Researchgate, dan WHO.

Pembahasan: Pada penderita hipertensi yang menderita COVID-19 terjadi peningkatan ekspresi ACE-2 yang menyebabkan tingginya kerentanan terhadap infeksi SARS-CoV-2. Gangguan fungsi sel-T dan peningkatan kadar interleukin-6 (IL-6) juga memainkan peran penting dalam peningkatan derajat keparahan penyakit COVID-19 pada penderita diabetes. Obesitas dapat menyebabkan abnormalitas pada sekresi sitokin, adipokin, dan inferferon yang akan menyebabkan terganggunya sistem imun pada tubuh manusia.

Simpulan: Mekanisme patofisiologi komorbid hipertensi, diabetes melitus, dan obesitas yang kompleks pada pasien COVID-19 meningkatkan derajat keparahan dan risiko kematian.
\end{abstract}

Kata Kunci: COVID-19, Diabetes, Hipertensi, Kematian, Obesitas 


\title{
HYPERTENSION, DIABETES MELLITUS, AND OBESITY AS THE MAIN COMORBIDITY FACTORS OF MORTALITY IN COVID-19 PATIENTS: A LITERATURE REVIEW
}

\begin{abstract}
Background: COVID-19 patients with comorbid diseases have a higher mortality rate than patients without congenital diseases. The most common comorbid found in COVID19 patients are diabetes mellitus, hypertension, and obesity. The prevalence of COVID19 patients with diabetes mellitus reached $41.7 \%$, hypertension reached $56.6 \%$, and obesity reached $41.7 \%$.

Methods: The method used in this paper is literature review from various references and focused on the correlation of comorbid with the risk of death in COVID-19 patients. The references are being retrieved from NCBI and Google Scholar. Overall, 21 sources were used which were obtained from various data bases including PubMed, ScienceDirect, Researchgate, and WHO.

Discussion: There is an increase in ACE-2 expression which causes a high susceptibility to SARS-CoV-2 infection on COVID-19 patient with hypertension. Impaired T-cell function and increased levels of interleukin-6 (IL-6) also play an important role in increasing the severity on COVID-19 patient with diabetes. Obesity can cause abnormalities in the secretion of cytokines, adipokines, and interferon which will disrupt the immune system in the human body.

Conclusion: The complex pathophysiological mechanisms of hypertension, diabetes mellitus, and obesity as comorbid in COVID-19 patients increase the severity and mortality risk.
\end{abstract}

Keywords: COVID-19, Diabetes, Hypertension, Mortality, Obesity 


\section{PENDAHULUAN}

Coronavirus Disease 2019 (COVID-19) saat ini mencapai lebih dari 120 juta kasus dengan angka kematian mencapai 2 juta kasus. [1] COVID-19 merupakan penyakit menular yang diakibatkan oleh Severe Acute Respiratory Syndrome Coronavirus-2 (SARS-CoV-2). SARS-CoV-2 dapat menyerang siapa saja dan mengakibatkan gejala atau tingkat keseriusan yang berbeda-beda, namun individu yang berusia di atas 60 tahun dengan penyakit penyerta seperti diabetes, penyakit pernapasan kronis, dan penyakit kardiovaskular berisiko lebih tinggi terkena infeksi. [2] Pasien COVID-19 dengan penyakit penyerta atau komorbid memiliki tingkat kematian yang lebih tinggi dibandingkan dengan pasien tanpa penyakit bawaan. ${ }^{[3]} \mathrm{Hal}$ ini didukung dengan penelitian yang menunjukan $88 \%$ kematian pada pasien positif SARS-CoV-2 disebabkan oleh riwayat komorbiditas. ${ }^{[4]}$ Selain itu, faktor prediktor lain yang menjadi penyebab tingginya mortalitas pada pasien pneumonia COVID-19 meliputi usia $\geq 65$ tahun, riwayat penyakit kardiovaskular atau serebrovaskular, sel $\mathrm{T} \mathrm{CD}^{+} \mathrm{CD}^{+}$ $\leq 75 \mathrm{sel} / \mu \mathrm{L}$, dan troponin $\mathrm{I} \geq 0,05 \mathrm{ng} / \mathrm{mL}$. [5]

Komorbid yang paling umum dijumpai pada pasien COVID-19 adalah diabetes melitus, hipertensi, dan obesitas. ${ }^{[6]}$ Prevalensi pasien COVID-19 dengan diabetes melitus mencapai $41,7 \%$, hipertensi mencapai $56,6 \%$, dan obesitas mencapai 41,7\%.

Peningkatan risiko kematian mencapai 1,95 kali pada pasien COVID-19 dengan hipertensi. ${ }^{[8]}$ Sedangkan risiko kematian meningkat sebanyak 2 kali pada pasien COVID-19 dengan diabetes melitus. ${ }^{[9]}$ Pasien COVID-19 dengan obesitas yang mendapatkan perawatan di rumah sakit juga mengalami peningkatan risiko kematian sebanyak 2 kali. ${ }^{[10]}$ Tujuan dari studi literatur ini adalah untuk mengetahui hubungan hipertensi, diabetes melitus, dan obesitas yang merupakan faktor komorbiditas utama sebagai penyebab kematian pada pasien COVID-19. Studi ini menjabarkan patofisiologi dari hipertensi, diabetes melitus, dan obesitas yang berpengaruh terhadap perburukan kasus infeksi
COVID-19 hingga meningkatkan risiko kematian.

\section{METODE}

Metode yang digunakan dalam penulisan ini adalah studi literatur yang relevan dari berbagai referensi dan terfokus pada hubungan komorbid dengan risiko kematian pada pasien COVID-19. Adapun mesin pencari yang digunakan dalam pencarian literatur antara lain National Center for Biotechnology Information (NCBI) dan Google Scholar dengan kata kunci COVID-19, 2019-nCoV, comorbid, hypertension, diabetes, obesity, mortality, dan mortality rate. Basis data diambil dari referensi yang dipublikasikan pada PubMed, ScienceDirect, Researchgate, dan World Health Organization (WHO). Secara keseluruhan digunakan sebanyak 30 sumber yang didapat dari berbagai basis data.

\section{PEMBAHASAN}

Epidemiologi dapat membantu kita memahami penyebaran COVID-19 melalui tiga komponen yaitu agen, lingkungan, dan inang. Dalam konteks COVID-19, agen tersebut adalah SARSCoV-2, termasuk patogenisitas dan virulensi berbagai strain. Lingkungan mengacu pada faktor ekstrinsik yang mempengaruhi agen dan peluang untuk terpapar seperti droplet pernapasan dan permukaan yang terkontaminasi. Inang atau host adalah setiap orang yang tidak terinfeksi dan karakteristik kerentanan individu mereka, seperti usia, jenis kelamin, dan penyakit penyerta. Dengan meminimalkan interaksi antara komponen-komponen ini akan mengurangi penyebaran COVID-19.

\subsection{Faktor Komorbiditas Utama}

Data tahun 2020 menunjukan bahwa hipertensi menjadi komorbid dengan jumlah kasus terbanyak pada pasien COVID-19 di Indonesia, yakni sebanyak 52,1\%.[11] Kedudukan hipertensi sebagai komorbid terbanyak pada pasien COVID-19 didukung oleh meta-analisis yang dilakukan pada tahun 2020 dan didapatkan hasil bahwa hipertensi menjadi komorbid terbanyak, yakni $21,1 \% .^{[12]}$ Sebuah kajian literatur 
menunjukan bahwa hipertensi menjadi komorbid yang paling sering pada pasien COVID-19 di berbagai negara seperti Cina, Italia, dan Amerika Serikat. ${ }^{[13]}$

Diabetes melitus menempati posisi kedua sebagai komorbid terbanyak pada pasien COVID-19 di Indonesia, yakni sebesar $33,6 \% .{ }^{[11]}$ Meta-analisis lainnya menunjukan bahwa diabetes melitus menempati posisi kedua sebagai komorbid terbanyak pada pasien COVID-19, yakni $9,7 \%{ }^{[12]}$ Diabetes juga menjadi komorbid dengan jumlah terbanyak kedua di berbagai negara seperti Cina, Korea Selatan, dan Amerika Serikat. ${ }^{[13]}$

Penelitian yang dilakukan pada awal pandemi COVID-19 menunjukan bahwa obesitas menjadi salah satu faktor komorbid tertinggi pada pasien COVID-19.[7, 14] Studi yang dilakukan di New York menunjukan obesitas memiliki prevalensi $41,7 \%$ sebagai komorbid pada pasien COVID-19.[7] Meskipun saat ini penelitian menunjukan bahwa obesitas tidak termasuk sebagai faktor komorbid tertinggi, obesitas dikaitkan dengan komorbid lainnya pada pasien COVID-19. Pasien COVID-19 dengan obesitas memiliki risiko lebih tinggi terhadap diabetes melitus tipe 2, penyakit kardiovaskular, dan gagal ginjal. ${ }^{[15]}$

\subsection{Hipertensi dan COVID-19}

Angiotensin Converting Enzyme tipe 2 (ACE-2) teridentifikasi sebagai reseptor target terhadap SARS-CoV2. ${ }^{[16]}$ ACE-2 menjadi reseptor fungsional spesifik bagi SARS-CoV-2 dan menjadi permulaan infeksi COVID-19. ${ }^{[17,}{ }^{18]}$ Coronavirus terdiri dari 4 protein struktural, yakni spike (S), membran (M), envelope (E), dan nukleokapsid (N). ${ }^{[19]}$ Spike pada SARS-CoV-2 dapat berikatan dengan reseptor ACE-2.[19] Setelah spike SARS-CoV-2 berikatan dengan reseptor ACE-2, selanjutnya akan terjadi aktivasi fusi membran virus dengan sel pejamu. $\left.{ }^{[17,} 18,19\right]$ Selain itu RNA virus akan dilepaskan ke sitoplasma dan memulai infeksi. ${ }^{[17]}$ Virus akan memasuki sel epitel pulmoner dan mampu bereplikasi..[16] Reseptor ACE-2 tersebar di berbagai jaringan berbeda terutama paru-paru, jantung, ileum, ginjal, dan vesika urinaria. ${ }^{[19]}$
Pada penderita hipertensi yang menderita COVID-19 terjadi peningkatan ekspresi ACE-2 yang menyebabkan tingginya kerentanan terhadap infeksi SARS-CoV-2, terutama pengobatan dengan angiotensin II receptor blocker (ARB) dan angiotensinconverting enzyme inhibitor (ACEi). [20, 21] Hal tersebut dapat berujung pada perburukan dan keparahan infeksi SARS-CoV-2 akibat peningkatan ikatan virus dengan sel target yang memanfaatkan ACE-2. ${ }^{[20,21,22]}$ Reseptor ACE-2 diekspresikan oleh sel endotelial, sehingga disfungsi pada sel endotel vaskular yang sering terjadi pada pasien hipertensi dapat meningkatkan peningkatan ekspresi reseptor ACE-2. [21] Sehingga disfungsi endotel vaskular pada pasien COVID-19 dengan hipertensi meningkatkan keparahan infeksi dan hingga risiko kematian. ${ }^{[21]}$

Beberapa penelitian justru menunjukan bahwa ACE-2 memiliki efek protektif dari cedera paru. [23] ACE-2 mengubah bentuk angiotensin II menjadi angiotensin 1-7 yang menurunkan reaksi inflamasi dari angiotensin II dan meningkatkan potensi efek antiinflamasi pada angiotensin 1-7. ${ }^{[23]}$ Pada pasien yang menderita hipertensi, ACEi dan ARB sering digunakan sebagai pilihan terapi untuk mempertahankan tekanan darah. ${ }^{[21]}$ Meskipun terdapat penelitian yang menunjukan bahwa penggunaan ARB dan ACEi dapat meningkatkan ekspresi $A C E-2$, saat ini rekomendasi terapi yang dianjurkan pada pasien COVID-19 adalah dengan melanjutkan pilihan terapi antihipertensi sebelumnya karena belum banyak penelitian yang mendukung teori tersebut. ${ }^{[24]}$ Penggunaan ACEi dan ARB sebagai terapi antihipertensi dapat menghambat formasi angiotensin II yang berkontribusi pada penurunan inflamasi pada paru, jantung, dan ginjal. [23] Hal tersebut memungkinkan ACEi dan ARB untuk menurunkan potensi perburukan kondisi pasien meliputi gangguan pernapasan berat akut, miokarditis, atau gagal ginjal akut yang dapat terjadi pada pasien COVID-19. [23] Meskipun masih terdapat kontroversi mengenai penggunaan ACEi dan ARB sebagai pilihan terapi antihipertensi pada pasien COVID-19 dengan hipertensi, namun didapatkan bahwa 
Sistem Renin-Angiotensin-Aldosteron (RAAS) berperan dalam peningkatan risiko kematian pada pasien COVID-19 dengan hipertensi.

\subsection{Diabetes dan COVID-19}

Patofisiologi utama virus SARSCoV-2 pada manusia adalah respon proinflamasi berat atau badai sitokin yang distimulasi oleh virus tersebut saat masuk ke tubuh manusia. ${ }^{[9]}$ SARS-CoV2 menggunakan reseptor ACE-2 sebagai pintu masuk ke sel tubuh manusia melalui ikatan dengan Sglikoprotein yang terdapat pada permukaan SARS-CoV-2. ${ }^{[25]}$ Masuknya virus ke dalam sel memicu respon inflamasi melalui sel $T$ pembantu yang memproduksi interferon y yang berujung pada badai sitokin. [25] Penelitian yang dilakukan pada tikus menunjukan pada kondisi diabetes terjadi peningkatan ekspresi pada reseptor ACE-2. [25] Penelitian tersebut juga didukung oleh didapatkannya peningkatan ekspresi ACE-2 pada pasien dengan diabetes melitus tipe 1 maupun tipe 2. [20]

Selain itu, pada kondisi diabetes juga terjadi peningkatan furin, protease membran tipe 1, yang berperan dalam proses masuknya SARS-CoV-2 ke dalam sel dan memfasilitasi replikasi virus. [25] Gangguan fungsi sel-T dan peningkatan kadar interleukin-6 (IL-6) juga memainkan peran penting dalam peningkatan derajat keparahan penyakit COVID-19 pada penderita diabetes. [2] Diabetes dapat meningkatkan keparahan infeksi COVID-19 bahkan meningkatkan risiko kematian yang diakibatkan oleh memanjangnya waktu membersihkan virus dari tubuh. [26] Pemanjangan tersebut dapat terjadi akibat penghentian aktivitas enzim Dipeptidyl Peptidase IV (DPP4) oleh penggunaan obat antidiabetes. ${ }^{[26]}$ Obatobatan tersebut memiliki aktivitas target pada DPP4 yang meningkatkan sekresi insulin dan menurunkan kadar gula darah, sedangkan DPP4 merupakan aminopeptidase pada membran sel yang berperan pada berbagai proses fisiologi termasuk respon imun. ${ }^{\text {[26] }}$

Penurunan fungsi makrofag juga menyebabkan peningkatan keparahan COVID-19 pada pasien dengan diabetes melitus. [26] Hiperglikemia kronis dan inflamasi dikenal sebagai penyebab respon imun yang abnormal dan tidak efektif akibat penurunan mobilisasi dari leukosit polimorfonuklear, kemotaksis, aktivitas fagosit, penurunan sekresi sitokin, serta inhibisi aktivitas Tumor Necrosis Alpha (TNFa) pada sel T. [26, 27] Melalui mekanisme patofisiologi tersebut meningkatkan risiko kematian pada pasien COVID-19 dengan diabetes melitus.

\subsection{Obesitas dan COVID-19}

Obesitas dapat menyebabkan abnormalitas pada sekresi sitokin, adipokin, dan interferon yang akan menyebabkan terganggunya sistem imun pada tubuh manusia. ${ }^{[2]}$ Jaringan adiposa pada obesitas disertai tingginya leptin yang merupakan proinflamasi yang dapat meningkatkan ekspresi sitokin dan adipokin. [28] Selain itu, terdapat disregulasi pada ekspresi leukosit jaringan dan makrofag yang berperan dalam respon inflamasi serta limfoid alami (innate lymphoid) yang berujung dengan gangguan pada respon imun. ${ }^{[28]}$ Obesitas menginduksi inflamasi kronis dengan peningkatan IL6 dan TNFa yang konsisten pada sirkulasi. ${ }^{[7]} \mathrm{Hal}$ tersebut menginduksi peningkatan infiltrasi makrofag ke jaringan adiposa. ${ }^{[7]}$

Konsentrasi IL- 6 dan TNF $\alpha$ pada serum menjadi faktor prediktor peningkatan derajat keparahan dan risiko kematian pada pasien COVID-19. [7] Gangguan pada respon imun akibat obesitas menurunkan respon sel sitotoksik pada sel imunokompeten yang menjadi peran utama sebagai anti-viral. [29] Reseptor ACE-2 yang diekspresikan pada jaringan adiposa lebih banyak dibandingkan pada paru. ${ }^{[30]}$ Sehingga pada obesitas dengan peningkatan massa jaringan adiposa menyebabkan peningkatan jumlah ekspresi reseptor ACE-2. $[28,29] \mathrm{Hal}$ ini menjadi alasan pasien COVID-19 dengan obesitas berisiko mengalami peningkatan derajat keparahan infeksi. ${ }^{[29]}$

Pasien obesitas berisiko lebih tinggi untuk mengalami gangguan lainnya seperti diabetes, hipertensi, penyakit kardiovaskular, dan penyakit serebrovaskular yang meningkatkan derajat keparahan dan risiko kematian pada pasien COVID-19. ${ }^{[28,29]}$ Obesitas juga memengaruhi volume, fungsi, dan 
ekspansi paru yang berdampak pada derajat keparahan penyakit. [29] Pada obesitas terdapat penurunan Forced Expiratory Volume dalam satu detik (FEV1) dan Forced Volume Capacity (FVC) serta menyebabkan penurunan kontraktilitas Diafragma. [28] Obesitas menyebabkan peningkatan resistensi saluran pernapasan, penurunan otot pernapasan, penurunan volume paru, dan gangguan pertukaran gas pada pasien. [30] Hal tersebut menyebabkan prognosis yang buruk dengan risiko komplikasi paru pada pasien COVID-19 dengan obesitas. ${ }^{[30]}$

\section{KESIMPULAN}

Komorbid yang menjadi penyebab utama kematian pada kasus COVID-19 antara lain hipertensi, diabetes melitus, dan obesitas. Hipertensi meningkatkan risiko kematian pada kasus COVID-19 melalui RAAS yang menstimulasi ekspresi ACE-2 sehingga meningkatkan kemampuan SARS-CoV-2 untuk masuk ke sel target.

Pada pasien COVID-19 dengan diabetes melitus memiliki derajat keparahan infeksi yang lebih tinggi seperti mengalami badai sitokin hingga risiko kematian. Penggunaan obat antidiabetes memiliki aktivitas target pada DPP4 yang meningkatkan sekresi insulin dengan DPP4 sebagai aminopeptidase pada membran sel yang berperan pada berbagai proses fisiologis termasuk respon imun. Hiperglikemia kronis menyebabkan respon imun yang abnormal dan tidak. Mekanisme tersebut selanjutnya meningkatkan risiko kematian pasien COVID-19 dengan diabetes melitus.

Obesitas sebagai komorbid pada pasien COVID-19 menimbulkan mekanisme respon yang serupa dengan hipertensi dan diabetes. Mekanisme tersebut antara lain peningkatan respon proinflamasi dan ekspresi reseptor ACE2 yang memperburuk badai sitokin. Obesitas juga memicu terjadinya gangguan sistem lain dengan risiko peningkatan derajat keparahan hingga risiko kematian.

\section{DAFTAR PUSTAKA}

1. World Health Organization, "WHO Coronavirus

Dashboard," 2021.

(COVID-19)

2. Ejaz H., A. Alsrhani, A. Zafar, H. Javed, K. Junaid, A. E. Abdalla, K. O. Abosalif, Z. Ahmed and S. Younas, "COVID-19 and comorbidities: Deleterious impact on infected patients," Journal of Infection and Public Health, vol. 13, pp. 1833-1839, 2020.

3. Parveen R., N. Sehar, R. Bajpai and N. B. Agarwal, "Association of diabetes and hypertension with disease severity in covid-19 patients: A systematic literature review and exploratory metaanalysis," Diabetes Research and Clinical Practice, vol. 166, no. 108295, pp. 1-8, 2020.

4. Grippo F., S. Navarra, C. Orsi, V. Manno, E. Grande, R. Crialesi, L. Frova, S. Marchetti, M. Pappagallo, S. Simeoni, L. D. Pasquale, A. Carinci, C. Donfrancesco, C. L. Noce, L. Palmieri, G. Onder and G. Minelli, "The Role of COVID-19 in the Death of SARS-CoV-2-Positive Patients: A Study Based on Death Certificates," Journal of Clinical Medicine, vol. 9, no. 3459, pp. 1-12, 2020.

5. Du R.-H., L.-R. Liang, C.-Q. Yang, W. Wang, T.-Z. Cao, M. Li, G.-Y. Guo, J. Du, C.-L. Zheng, Q. Zhu , M. $\mathrm{Hu}, \mathrm{Xu}-$ Yan, Peng Peng and H.-Z. Shi, "Predictors of Motality for Patients with COVID-19 Pneumonia Caused by SARS-CoV-2: A Prospective Cohort Study," European Respiratory Journal, vol. 55, no. 2000524, pp. 1-8, 2020.

6. Sanyaolu A., C. Okorie and M. Altaf, "Comorbidity and its impact on patients with COVID-19," Sn Comprehensive Clinical Medicine, vol. 2, pp. 1-8, 2020.

7. Caci G., A. Albini, M. Malerba, D. M. Noonan, P. Pochetti and R. Polosa, "COVID-19 and Obesity: Dangerous Liaisons," Journal of Clinical Medicine, vol. 9, no. 2511, pp. 1-12, 2020. 
8. Biswas M., S. Rahaman, T. K. Biswas, Z. Haque and B. Ibrahim, "Association of Sex, Age, and Comorbidities with Mortality in COVID-19 Patients: A Systematic Review and Meta-Analysis," Intervirology, vol. 64, pp. 36-47, 2021.

9. Alkundi A. and R. Momoh, "COVID19 infection and diabetes mellitus," Journal of Diabetes, Metabolic Disorders \& Control, vol. 7, no. 4, pp. 119-120, 2020.

10. Czernichow S., N. Beeker, C. RivesLange, E. Guerot, J.-L. Diehl, S. Katsahian, J.-S. Hulot, T. Poghosyan, C. Carette and A.-S. Jannot, "Obesity Doubles Mortality in Patients Hospitalized for (SARSCoV-2) in Paris Hospitals, France: A Cohort Study on 5,795 Patients," Obesity Journal, vol. 28, no. 2, pp. 2282-2289, 2020.

11. Karyono D. R. and A. L. Wicaksana, "Current prevalence, characteristics, and comorbidities of patients with COVID-19 in Indonesia," Journal of Community Empowerment For Health, vol. 3, no. 2, pp. 77-84, 2020.

12. Yang J., Y. Zheng, X. Gou, K. Pu, Z. Chen, Q. Guo, R. Ji, H. Wang, Y. Wang and Y. Zhou, "Prevalence of comorbidities and its effects in patients infected with SARS-CoV-1: a systematic review and metaanalysis," International Journal of Infectious Diseases, vol. 94, pp. 9195, 2020.

13. Bajgain K. T., S. Badal, B. B. Bajgain and M. J. Santana, "Prevalence of comorbidities among individuals with COVID-19: A rapid review of current literature," American Journal of Infection Control, vol. 49, pp. 238-246, 2021.

14. Zhou Y., Q. Yang, J. Chi, B. Dong, W. Lv, L. Shen and Y. Wang, "Comorbidities and the risk of severe or fatal outcomes associated with coronavirus disease 2019" A systematic review and metaanalysis," International Journal of Infectious Diseases, vol. 99, pp. 4756, 2020.
15. Aghili S. M. M., M. Ebrahimpur, B. Arjmand, Z. Shadman, M. P. Sani, M. Qorbani, B. Larijani and $M$. Payab, "Obesity in COVID-19 era, implications for mechanisms, comorbidities, and prognosis: a review and meta-analysis," International Journal of Obesity, vol. 45, pp. 998-1016, 2021.

16. Cevik M., K. Kuppalli, J. Kindrachuk and M. Peiris, "Virology, transmission, and pathogenesis of SARS-CoV-2," BMJ Journal, vol. 371, pp. 1-6, 2020.

17. Ni W., X. Yang, D. Yang, J. Bao, R. Li, Y. Xiao, C. Hou, H. Wang, J. Liu, D. Yang, Y. Xu, Z. Cao and Z. Gao, "Role of angiotensin-converting enzyme 2 (ACE2) in COVID-19," Critical Care, vol. 24, no. 422, pp. 110, 2020.

18. Parasher A., "COVID-19: Current understanding of its pathophysiology, clinical presentation and treatment," BMJ Journal, vol. 97, pp. 312-320, 2021.

19. Yuki K., M. Fujiogi and S. Koutsogiannaki, "COVID-19 pathophysiology: A review," Clinical Immunology, vol. 215, pp. 1-7, 2020.

20. Pititto B. d. A. and S. R. G. Ferreira, "Diabetes and covid-19: more than the sum of two morbidities," Revista de Saude Publica, vol. 54, no. 54, pp. 1-6, 2020.

21. Kario K., Y. Morisawa, A. Sukonthasarn, Y. Turana, Y.-C. Chia, S. Park, T.-D. Wang, C.-H. Chen, J. C. Tay, Y. Li and J.-G. Wang, "COVID-19 and hypertension-evidence and practical management: Guidance from the HOPE Asia Network," The Journal of Clinical Hypertension, vol. 22, no. 7, pp. 1109-1119, 2020.

22. Kulkarni S., B. L. Jenner and I. Wilkinson, "COVID-19 and hypertension," Journal of the ReninAngiotensin-Aldosterone System, vol. 21, no. 2, pp. 1-5, 2020.

23. Schiffrin E. L., J. M. Flack, S. Ito, P. Muntner and R. C. Webb, "Hypertension and COVID-19," American Journal of Hypertension, vol. 33, no. 5, pp. 373-374, 2020. 
24. Azer S. A., "COVID-19: pathophysiology, diagnosis, complications and investigational therapeutics," New Microbes and New Infections, vol. 37, no. 100738, pp. 1-8, 2020.

25. Singh A. K., R. Gupta, A. Misra and A. Ghosh, "Diabetes in COVID-19: Prevalence, pathophysiology, prognsis and practical considerations," Diabetes \& Metabolic Syndrome, vol. 14, no. 4, pp. 303-310, 2020.

26. Abdi A., M. Jalilian, P. A. Sarbarzeh and Vlaisavljevic, "Diabetes and COVID-19: A systematic review on the current evidences," Diabetes Research and Clinical Practice, vol. 166, no. 108347, pp. 1-13, 2020.

27. Holman N., P. Knighton, P. Kar, J. O. Keefe, M. Curley, A. Weaver, E. Barron, C. Bakhai, K. Khunti, N. J. Wareham, N. Sattar, B. Young and J. Valabhji, "Risk factors for COVID19-related mortality in people with type 1 and type 2 diabetes in England: a population-based cohort study," Lancet Diabetes Endocrinal, vol. 8, pp. 823-833, 2020.

28. Sattar N., I. B. Mclnnes and J. J. V. McMurray, "Obesity Is a Risk Factor for Severe COVID-19 Infection," American Heart Association, vol. 142, no. 1, pp. 1-6, 2020.

29. Hussain A., K. Mahawar, Z. Xia, W. Yang and S. EL-Hasani, "Obesity and mortality of COVID-19: Metaanalysis," Obesity Research \& Clinical Practice, vol. 15, no. 1, pp. 100-105, 2021.

30. Yu W., K. E. Rohli, S. Yang and P. Jia, "Impact of obesity on COVID-19 patients," Journal of Diabetes and lts Complications, vol. 35, no. 107817 , pp. 1-14, 2021. 